Hichem Dkhili,

College of Business Administration, Northern Border University, Saudi Arabia,

University of Jendouba, Tunisia

Lasaad Ben Dhiab,

College of Business Administration, Northern Border University, Saudi Arabia

\title{
MANAGEMENT OF ENVIRONMENTAL PERFORMANCE AND IMPACT OF THE CARBON DIOXIDE EMISSIONS (CO2) ON THE ECONOMIC GROWTH IN THE GCC COUNTRIES
}

Abstract. This paper summarizes the arguments and counterarguments within the scientific discussion on the issue the Management of Environmental Performance and the Carbon Dioxide Emissions (CO2) on the Economic Growth, with an innovative study in the context of the GCC countries. The main goal of the paper is to examine empirically the environmental Kuznets curve hypothesis for the GCC countries. The methodological tool of this contribution tries to measure the effect of the emission of the $\mathrm{CO} 2$ on the Growth Economic and environmental performance. The main purpose of the research is focused on the empirical approach justified by the use of a dynamic panel modeling on a sample of the GCC countries during the period of 2002-2018. Systematization literary sources and approaches for solving the problem of the reaction of the development of the Environmental Performance with the level of the the Carbon Dioxide Emissions (CO2) and the economic growth. The study employed a GMM model system. Subsequently, the authors displayed a Panel Co-integration test of Pedroni (2004), the Kao Residual Cointegration test (1999), and the Granger causality tests. The results found unidirectional causal relationships between economic growth and the entire variable of the sample, except the variable $\mathrm{CO} 2$ emission. These relationships are statistically significant at the level of 5\%. For the relation between Economic Growth and CO2 emission, one the hypothesis of the paper was checking a non-significant and unidirectional relationship. The results showed a long-run unidirectional causality between the variables and implied that Economic Growth in the GCC countries has a positive and significant unidirectional relation with Environment Performance, trade openness, foreign direct investment, and investment. The results confirm the existence of a negative relationship as insignificant, and unidirectional, between economic growth and $\mathrm{CO} 2$ emissions in the GCC countries. Finally, this finding doesn't support the validity of the EKC hypothesis and provide information's to take the necessary policy suggestions to maintain the environmental performance and limit the average of the $\mathrm{CO} 2$ emissions. The results of the research can be useful for the GCC countries to avoid the higher level of Carbon Dioxide Emissions (CO2) and maintain a good Environmental Performance.

Keywords: environmental performance, Environmental Kuznets Curve, $\mathrm{CO} 2$ emissions.

Introduction. The focus of the current environment shows a changing, uncertain, multiple and complex environment. Located today in such an environment, companies are forced to evaluate their opportunities and threats in terms of constraints. In this way, the environmental performance has been considered as one of the most important concern.

Several scientific articles have resumed studies focusing on the analysis of determinants of environmental performance against different dimensions such as economic growth and carbon dioxide emissions in many countries. Environmental performance is defined as a multidimensional concept that is difficult to measure because it relates to the percentage of environmental pollution, energy consumption and various administrative programs that are adopted and then implemented to reduce these negative impacts of emissions of harmful gases to the environment.

Given the importance of these topics, the number of scientific articles and research has been addressed in several contexts. For example, the study Altwaijri et al., (2004) suggested a model of «good» environmental performance, which is largely associated with "good» economic performance. Furthermore, the study of Bohringer and Ochem (2007) showed that country sustainability indicators provide a one-dimensional measure for assessing country-specific information on the three dimensions of

Cite as: Dkhili, H., Dhiab, L. B. (2019). Management of Environmental Performance and Impact of the Carbon Dioxide Emissions (CO2) on the Economic Growth in the GCC Countries. Marketing and Management of Innovations, 4, 252-268. http://doi.org/10.21272/mmi.2019.4-20 
H. Dkhili, L. B. Dhiab. Management of Environmental Performance and Impact of the Carbon Dioxide Emissions (CO2) on the Economic Growth in the GCC Countries

sustainable development: economic, environmental and social conditions. We also mention the contribution of Cracolici et al. (2010) to the development of a new analytical framework for the assessment of spatial disparities between countries. It provided a combination of economic and non-economic (mainly social) aspects of a country's performance in an integrated logical framework. On the other hand, the study Zhou et al., (2010) dealt with the relationship between environmental disclosure and management of institutional impressions to investigate two subsequent hypotheses using a cross-sectional sample of environmental disclosures of US companies in annual reports.

In this context, this contribution try to study the EKC hypothesis followed by the environmental regulations or degradation, measured by the $\mathrm{CO} 2$ emissions, with economic and macroeconomic variables. This context, this debate was raised by the research conducted by Grossman and Krueger (1991), which focused on the relationship between air quality and economic growth.

In the same wake, Kuznets (1955) oriented the research to discover the link between changes in income and growth. He took in his work as a reference to the four key elements of economic growth (demographic growth, growth of knowledge, in-country adaptation to growth factors, and external economic relations between the countries.

Later, Yandle et al. (2002) declared that the Environmental Kuznets Curve (EKC) has become standard fare in technical conversations about environmental. As far as, the contribution of Bhattarai and Hammig (2001) tried to test the relationship between deforestation and income across 66 countries of Latin America. Then, Bilgili and Umit Bulut (2016) investigated a revisited Environmental Kuznets Curve (EKC) hypothesis with the potential impact of renewable energy consumption on environmental quality. In which, this authors advanced that the validity of EKC does not depend on the income level of individual countries of a panel in which EKC hypothesis holds.

Also, the works of Bakirtas and Atalay Cetin (2017) examine the validity of the environmental Kuznets curve (EKC) and pollution haven hypotheses in MIKTA countries (Mexico, Indonesia, South Korea, Turkey, and Australia from 1982 to 2011.

Thus, the Environmental Performance Index (EPI) is a composite indicator that tracks a variety of socio-economic, environmental and institutional indicators that characterize and affect environmental sustainability at the national level. It was launched in 1999 by Professor Daniel Este, Director of Yale Center for Environmental Law and Policy, in collaboration with CIESIN Center and World Leader of the World Summit for the Global Future of the World Economic Forum.

Finally, our contributions set out the environment Kuznets curve (EKC) hypothesis, and try to answer the question of the relationship between environmental performance as compared to economic growth and the degree of carbon dioxide emissions. In this context we have relied on studies: Pablo-Romero et al. (2017); Gallego-Ilvarez (2014); Almeida and Garcia-Sanchez (2017); Echavarren, (2016); Ahmad et al. (2017); Tamazian and Bhaskara Rao (2010); Jamali and al., (2017); Chikalipah and Makina (2019); Grossman and Krueger (1991), Bilgili and Umit Bulut (2016); Apergis and Ozturk, (2015); Azam and Khan (2016); and Liu et al. (2017).

This purpose aims to determine the relationship between environmental performances, economic growth towards the degree of carbon dioxide emissions in the GCC countries. We will rely on a pilot model of the Environmental Performance Index (EPI) against economic growth indicators and carbon dioxide emissions for the sample of GCC countries between 2002 and 2018. In this case, our problematic is: What are the coincidences of Economic Growth on $\mathrm{CO} 2$ emissions and environmental performance?

The first part of the paper reviews the theoretical and empirical literature on the relationship between the variables of the study. In the second part, we propose an empirical investigation. Finally, we advance the interpretation and discussion of the results.

Literature Review. The review of the literature has branded several studies conducted in different contexts, which are interested in the problem of issuance of $\mathrm{CO} 2$ towards economic growth. For example, 
H. Dkhili, L. B. Dhiab. Management of Environmental Performance and Impact of the Carbon Dioxide Emissions (CO2) on the Economic Growth in the GCC Countries

we cite the studies of Sugiawan et al. (2019), Churchill et al. (2019), He et al. (2019), Miao et al. (2019), and Ershad and Haque (2019), Yang et al. (2019), Saboori et al. (2010), He et al. (2019b).

Also, many authors had analyzed the relationship between environmental performance and economic growth and CO2 emissions (e.g. Saidi and Mbarek, 2017; Boutabba, 2014; Shahbaz et al., 2013a; Shahbaz et al., 2013b; Salahuddin et al., 2015; Shuai et al., 2017; Bekhet and Othman, 2017; Liu et al., 2017; Kaushik et al., 2006; Ouyang and Lin, 2017; Dkhili and Ben Dhiab, 2019; He et al., 2017; Zhang et al., 2017; and Fodha and Zaghdoud, 2010).

Especially, the review of Saini and Sighania (2019) in which the authors have examined the relationship between economic development and carbon emission and its impact on the environment on the basis of 111 research papers from a sample of thousands of papers.

At present, our theoretical and empirical contribution is conceived in the study of environmental performance and economic growth alternating with their impact on CO2 emissions. He et al. (2019a) explore the relationship between environmental tax, environmental performance, and economic development in China and Sweden. The founding of these studies shows that environmental tax is related negatively to carbon dioxide. Shahbaz et al. (2013a) study the effects of financial development, economic growth, coal consumption and trade openness on environmental performance using time series data over the period 1965-2008 in the case of South Africa. And they prove a long-run relationship among the variables. Results showed that a rise in economic growth increases energy emissions, and coal consumption has significant contribution to deteriorate environment in the South African economy. Sugiawan et al. (2019) investigate the impact of CO2 emission reduction on sustainable well-being with the future growth of $\mathrm{CO} 2$ emissions and Inclusive Wealth. They conclude that the reduction of the $\mathrm{CO} 2$ emission might increase the wealth gain. The studies of Churchill et al. (2019) examine the relationship between ethnic diversity and environmental quality, peroxided by carbon dioxide (CO2) emissions, and based on a model for economic growth. And they found that ethnic fractionalization reduces $\mathrm{CO} 2$ emissions with a positive effect on growth in high-income countries.

In the context of South Africa, Bekun et al. (2019) explore energy use and economic growth. The results of the study prove an inverted $U$-shaped pattern between energy use and economic growth in the long run. Finally, the author's notes, at a higher level of economic development, there is less intensification of energy consumption, and a decline in energy intensity while validating energy efficiency in South Africa. Similarly, Saini and Sighania (2019) propose to organize a detailed review of economic growth, carbon emission, and foreign capital inflows and its impact on the environment. And they found that a significant amount of literature is available which supports cleaner FDI as a measure to mitigate the negative effects of economic growth on the ecological environment.

Then Miao et al., (2019) estimate the atmospheric environmental performance under the constraints of energy and atmospheric pollutant. While, Dang (2019), use the Environmental Kuznets Curve (EKC) model, to study the environmental impacts of institutional variables in their relationships with foreign direct investment (FDI) in 23 developing countries. Thereafter the author highlights the importance of institutional reform in the pursuit of sustainable development in the developing world.

After that, the purpose of Khan (2019) examines the role of poverty and logistical operations under the circumstance of environmental deterioration with panel data from 2007 to 2017 . The results indicate that poverty and logistical operations have a significant and positive relationship with greater environmental degradation.

Otherwise, we state the study of Azam et al. (2019), that treats the role of energy that cannot be passed over in the process of economic growth and development in any economy. The result of the study reveals that energy consumption has a significant positive impact on FDI, health, environment, and economic growth. More specifically, the studies of Sheng et al. (2019) interested in the effect of 
H. Dkhili, L. B. Dhiab. Management of Environmental Performance and Impact of the Carbon Dioxide Emissions (CO2) on the Economic Growth in the GCC Countries

urbanization and on $\mathrm{CO} 2$ emissions. The empirical results indicate that the relationship between urbanization and $\mathrm{CO} 2$ emissions.

In this case, Chen et al. (2019) explored the effects of economic growth (EG), renewable energy consumption (REC) and non-renewable energy consumption (NREC) on CO2 emissions (CE) and tested the Environmental Kuznets Curve (EKC) hypothesis at the regional levels in China. Yang et al. (2019) contributions focused on the causal effect of environmental policy on regional economic growth.

Whereas, Ershad and Haque (2019) investigate the relationship between economic growth and the earth's environment in 127 developing countries spreading all across the globe (Asia, Africa, Americas, Europe, and Polynesia) from 2007 to 2015. And they result in a relationship between the environmental performance of a country and the per capita GDP. He et al., (2019b) investigate the relationship between environmental degradation (ecological footprint) and economic indicators such as gross domestic product (GDP), financial liberalization, energy consumption, urbanization, and trade openness in Malaysia. The result shows a positive relationship between GDP, trade openness, energy consumption, and ecological footprint.

In addition, the literature review has provided several empirical works in a variety of contexts. That we can mention the work of Liu et al. (2017), Ozturk and Al-Mulali (2015), Saboori and Sulaiman (2013), Tan et al. (2014), Tang and Tan (2015), Tiwari et al. (2013), Yin, et al. (2015), Acaravci and Ozturk (2010), AlMulali et al. (2016), Ang (2007), Apergis and Ozturk (2015), Atasoy (2017), Azam and Khan (2016), Bakirtas and Atalay (2017), Cetin (2017), Bhattarai and Hammig (2001), Grossman and Krueger (1991), Shahbaz et al. ( 2012), Jayanthakumaran and Liu (2012), and Bilgili and Umit Bulut (2016).

The working paper of Grytten and Koilo (2019) test empirically the relationship of economic development, measured as economic growth, energy use, trade and foreign direct investment, and carbon dioxide $\mathrm{CO} 2$ emissions, in the context of eleven emerging Eastern European countries, and during the period of 1990 to 2014. The results of this study prove a positive effect of foreign direct investment (FDI) on $\mathrm{CO} 2$ emissions, and a negative effect of total energy consumption on the environment as it increases $\mathrm{CO} 2$ emissions.

Next parts of the Environmental Kuznets Curve (EKC) framework, Sinha et al. (2019) investigate the impact of corruption in public sector on carbon emissions in the context of Brazil-Russia-India-China-South Africa (BRICS) and over the period of 1990-2017. The results make out the incidences of environmental degradation on renewable energy consumption with a positive impact. This results Later, the results of Sinha et al. (2019) support with the Environmental Kuznets Curve (EKC) hypothesis and show that the real income and energy consumption.

Lesakova and Dobes (2018) have tried to verify the validity of the environmental Kuznets curve (EKC) on $\mathrm{CO} 2$ emissions. In their purpose, Lesakova and Dobes (2018) test the relationship between economic growth and the environment pressure, in the Czech Republic between 1970 and 2016. Thus the results found to proclaim the rejection of the validity of the environmental Kuznets curve (EKC) on $\mathrm{CO} 2$. $\mathrm{He}$ and Richard (2010), the authors test the relationship between per-capita GDP and per-capita pollutant emissions and find a little evidence for supporting the environmental Kuznets curve hypothesis.

In the same context that is interested in the framework of the environmental Kuznets curve (EKC). The empirical study of Mahmoud et al. (2019), treat the role of biomass energy in carbon dioxide (CO2) emissions in Pakistan over the period from 1980 to 2015. In which their results promote the validity of the framework of the environmental Kuznets curve (EKC).

Cetin and Ecevit (2017) upgrade to the impact of economic growth, energy consumption and trade openness on the carbon emissions in the case of Turkey for the 1960-2011 period. The results of their results provide a long-run relationship between the variables and the validity of the environmental Kuznets curve (EKC) hypothesis for Turkey. 
H. Dkhili, L. B. Dhiab. Management of Environmental Performance and Impact of the Carbon Dioxide Emissions (CO2) on the Economic Growth in the GCC Countries

The objective of the study Chang (2015) interested in the environmental improvement suggestions for the $\mathrm{G} 7$ group and BRICS group. The results do not satisfy the environmental Kuznets curve hypothesis.

Also, Lee et al. (2010) headed to the study of the environmental Kuznets curve (EKC) hypothesis for water pollution by using a recent dynamic technique. The results of these authors don't support the validity of the environmental Kuznets curve (EKC) hypothesis. Apergis and Payn (2009) are interested in the causal relationship between carbon dioxide emissions and energy consumption. Their results show longrun equilibrium energy consumption with a positive and statistically significant impact on emissions. Afterwards, Apergis and Payn (2009) validate the Environmental Kuznets Curve (EKC) hypothesis.

The paper of Gill et al. (2018) examines the presence of the environmental Kuznets curve (EKC) for greenhouse gases (GHG) measured by CO2 emission in Malaysia for the period 1970 to 2011. The results of this study (Gill et al., (2018)) prove that a high level of economic growth for the EKC cannot reverse the environmental degradation in Malaysia.

Kang et al. (2016) used a spatial panel data to analyze the CO2 EKC hypothesis of China. Their results mark the relationship between economic growth and $\mathrm{CO} 2$ emissions shapes as an inverted-N trajectory. More concretely the authors raise a Spatial spillovers effects are confirmed to affect the shape of the CO2. Kasman and Duman (2015) study the causal relationship between energy consumption, carbon dioxide emissions, economic growth, trade openness and urbanization for a panel of new EU member and candidate countries over the period 1992-2010. For the results of Kasman and Duman (2015), the authors affirm the validity of the EKC hypothesis. They find coefficients of lagged error correction term in the carbon dioxide emissions, energy consumption, GDP, and trade openness equations are statistically significant. Lau et al. (2014) are interested in the relationship between economic growth and CO2 emissions for Malaysia. The results of Lau et al. (2014) may be sufficient to confirm that the inverted-U shaped relationship does exist between economic growth and $\mathrm{CO} 2$ emission in both the short- and long-run for Malaysia. Consequently, the authors confirm the validity of the EKC hypothesis.

Likewise, the study of Grossman and Krueger (1995) investigated the relationship between per capita income and various environmental indicators. Therefore Grossman and Krueger (1995) find the rejection of the relationship between environmental quality and economic growth.

Methodology and research methods. This section may be divided by subheadings. It should provide a concise and precise description of the experimental results, their interpretation as well as the experimental conclusions that can be drawn.

The current study focuses on the relationship between environmental performance, economic growth and the $\mathrm{CO} 2$ emissions in GCC countries over the period 2002-2018. In this context, an empirical investigation is based on the use of econometric modelling. And, to test the relationship between the variables, we used a panel composed of a sample of six GCC countries observed over the period 20022018. We operate the Johansen and Juselius (1990) cointegration technique, and the Granger causality test. This last is applied, in order to check the direction of short-run and long-run causalities between environmental performance, economic growth, and $\mathrm{CO} 2$ emissions. We will be based on the following scheme:

First, a standard model will be developed to study the impacts of these relationships on environmental performance, economic growth, and carbon dioxide emissions. The Data were collected from (WDI): The World Development Indicators for economic growth. And from the data set of the website Knoema site for environmental performance indicators and carbon dioxide emissions. The environment performance index is collected from (YCELP: Yale Center for Environmental Law and Policy (YCELP), Yale University) and (CIESIN: Center for International Earth Science Information Network (CIESIN). The access to these data is done through the web site Knoema.

Secondly, a review of the various modern literary views on environmental performance, economic growth and carbon dioxide emissions under the Environmental Kuznets Curve (EKC) hypothesis. 
H. Dkhili, L. B. Dhiab. Management of Environmental Performance and Impact of the Carbon Dioxide Emissions (CO2) on the Economic Growth in the GCC Countries

Furthermore, we remark that all the majority of the literature follows a quadratic model to test the validity of the EKC hypothesis, as is in the summarized studies mentioned in table 1 above.

Table1. Definition of variables

\begin{tabular}{|c|c|c|c|}
\hline Variable & Definition & Measurement & Source \\
\hline GDPG & $\begin{array}{c}\text { The annual percentage growth rate of GDP at } \\
\text { market prices based on constant local currency }\end{array}$ & GDP growth (annual \%) & WDI (2002-2018) \\
\hline GDPSQ & $\begin{array}{c}\text { The annual percentage growth rate of GDP } \\
\text { squared }\end{array}$ & $\begin{array}{c}\text { GDP growth (annual \%) } \\
\text { squared }\end{array}$ & The author's calculation \\
\hline EPI & Environnemental performance index. & Index ranks & Knoema (2002-2018) \\
\hline CO2E & CO2 emissions (metric tons per capita) & $\begin{array}{c}\text { CO2 emissions (metric } \\
\text { tons per capita) }\end{array}$ & $\begin{array}{c}\text { WDI (2002-2014) } \\
\text { Knoema (2015-2018) }\end{array}$ \\
\hline INVES & $\begin{array}{c}\text { Gross fixed capital formation (formerly gross } \\
\text { domestic fixed investment) }\end{array}$ & $\begin{array}{c}\text { Gross fixed capital } \\
\text { formation (\% of GDP) }\end{array}$ & WDI (2002-2018) \\
\hline FDI & $\begin{array}{c}\text { The net inflows of investment to acquire a } \\
\text { lasting management interest. }\end{array}$ & $\begin{array}{c}\text { Foreign direct } \\
\text { investment, net inflows } \\
\text { (\% of GDP) }\end{array}$ & WDI (2002-2018) \\
\hline TRADE & $\begin{array}{c}\text { Trade is the sum of exports and imports of } \\
\text { goods and services measured as a share of } \\
\text { gross domestic product. }\end{array}$ & $\begin{array}{c}\text { Trade (\% of GDP) } \\
\text { Trand (2002-2018) }\end{array}$ & WDI \\
\hline
\end{tabular}

Sources: developed by the authors.

$$
E=f\left(Y, Y^{2}, Z\right)
$$

where, E, Y, Y2,$Z$ represent respectively, the COE emissions, the GDP, GDP squared, and the others factors affecting the environment like the (EPI), (FDI), (TRAD), (FDI), and the (INVEST)

For our study, the model is presented below in equation (2):

$$
C O 2=f\left(G D P, G D P^{2}, E P I, T R A D, F D I, I N V E S T\right)
$$

To study the relationship between the environmental performance, economic growth and the $\mathrm{CO} 2$ emissions in GCC countries, the equation (2) can be expressed in this manner:

$$
\mathrm{CO}_{2} \mathrm{E}_{\mathrm{i}, \mathrm{t}}=\beta_{0}+\beta_{1 \mathrm{i}} \mathrm{GDPG}_{\mathrm{i}, \mathrm{t}}+\beta_{2 \mathrm{i}} \mathrm{GDPG}_{\mathrm{i}, \mathrm{t}}^{2}+\beta_{3 \mathrm{i}} \mathrm{EPI}_{\mathrm{i}, \mathrm{t}}+\beta_{4 \mathrm{i}} \mathrm{INVEST}_{\mathrm{i}, \mathrm{t}}+\beta_{5 \mathrm{i}} \mathrm{FDI}_{\mathrm{i}, \mathrm{t}}+\beta_{6 \mathrm{i}} \mathrm{TRAD}_{\mathrm{i}, \mathrm{t}}+\varepsilon_{\mathrm{i}, \mathrm{t}}
$$

where (i) indicate the countries ( $i=1 \ldots 6$ ) and $t$ indicates the time period ( $t=2002 \ldots 2018)$; EPI, GDPG, GDPG2, CO2E, INVEST, INVEST, and TRAD represent the environmental performance, the real gross domestic product growth per capita, the square of the real gross domestic product growth per capita, and (CO2E) the CO2 emissions. (INVEST): is the Gross fixed capital formation. (TRAD) is the trade openness, the value added ( $\%$ of GDP). The signs of $\beta_{1}, \beta_{2}, \beta_{3}, \beta_{4}$, and $\beta_{5}$ are expected to be positive and negative, respectively, in order to reflect the inverted $U$-shape pattern.

To test the relationship between environmental performance, economic growth, and $\mathrm{CO} 2$ emissions in the GCC countries, during the period (2002-2018) for six (6) GCC countries namely Saudi Arabia, Bahrain, Kuwait, Oman, Qatar, and the United Arab Emirates.

Results. Table 2 and the figure $1 / 2$ present the annual average of the evolution of the economic growth, environmental performance index and CO2 emission in the GCC countries, 2002-2017. The 
H. Dkhili, L. B. Dhiab. Management of Environmental Performance and Impact of the Carbon Dioxide Emissions (CO2) on the Economic Growth in the GCC Countries

results show a higher average of the economic growth in the year (2004) with an environmental performance index (59.105\%), and a (61.885\%) of CO2 emissions. After the year (2004), we look that GCC countries are more interested to reduce the level of the $\mathrm{CO} 2$ emissions, and they tried to maintain the level of environmental performance index (EPI).

Table 2. Annual average evolution of growth, environmental performance index and $\mathrm{CO} 2$ emission in the GCC countries, 2002-2017

\begin{tabular}{|c|c|c|c|}
\hline Years & GDPG & EPI & CO2E \\
\hline $\mathbf{2 0 0 2}$ & 2.052 & 58.602 & 61.885 \\
\hline $\mathbf{2 0 0 3}$ & 7.406 & 58.847 & 61.885 \\
\hline $\mathbf{2 0 0 4}$ & 9.297 & 59.105 & 61.885 \\
\hline $\mathbf{2 0 0 5}$ & 6.210 & 59.240 & 61.885 \\
\hline $\mathbf{2 0 0 6}$ & 9.693 & 59.068 & 67.501 \\
\hline $\mathbf{2 0 0 7}$ & 6.959 & 58.703 & 67.501 \\
\hline $\mathbf{2 0 0 8}$ & 7.338 & 58.555 & 67.501 \\
\hline $\mathbf{2 0 0 9}$ & 1.038 & 58.547 & 60.135 \\
\hline $\mathbf{2 0 1 0}$ & 5.501 & 59.627 & 60.135 \\
\hline $\mathbf{2 0 1 1}$ & 6.801 & 61.138 & 60.135 \\
\hline $\mathbf{2 0 1 2}$ & 5.712 & 61.020 & 60.135 \\
\hline $\mathbf{2 0 1 3}$ & 3.850 & 64.947 & 60.135 \\
\hline $\mathbf{2 0 1 4}$ & 3.272 & 61.023 & 60.135 \\
\hline $\mathbf{2 0 1 5}$ & 3.504 & 65.847 & 60.135 \\
\hline $\mathbf{2 0 1 6}$ & 3.131 & 67.193 & 78.248 \\
\hline $\mathbf{2 0 1 7}$ & 0.254 & 69.377 & 78.248 \\
\hline
\end{tabular}

Sources: systematised by the authors on the basis of $(2002,2017)$.

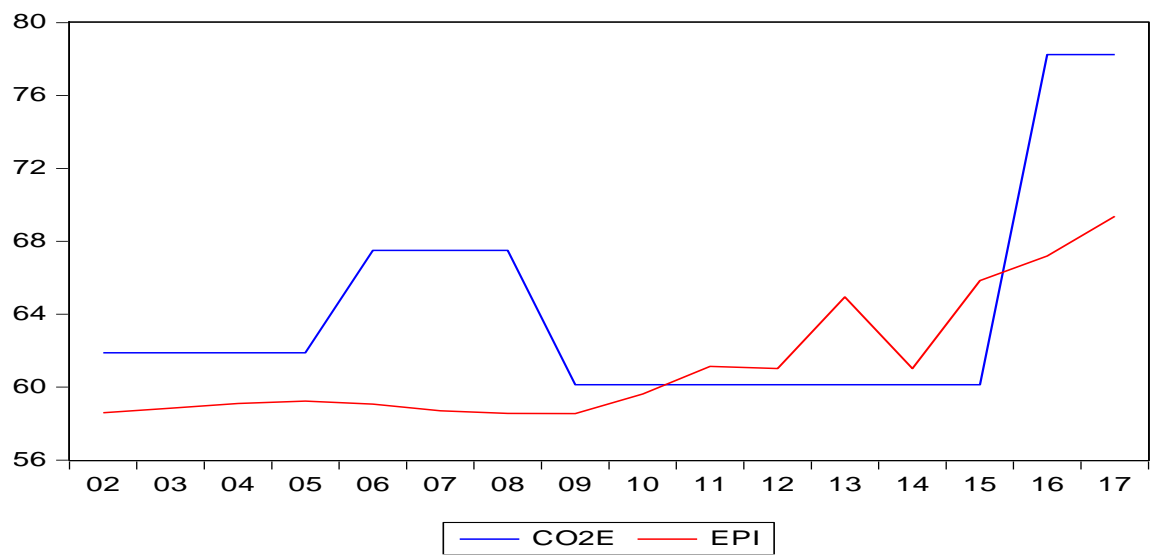

Figure1. Average evolution of CO2E and EPI in GCC countries

Concretely, these actions are more clearly since the years (2011) to (2017). The GCC countries ended in the years (201) by a rate of economic growth equal to $(0.254 \%)$, a higher environmental performance index (EPI) equal to (69.377\%) and level of CO2 emissions equal to $(78.248 \%)$

Finally, we prove a decline in the rate of (GDPG) against an increase of the environmental performance index (EPI), and the level of $\mathrm{CO} 2$ emissions. 
H. Dkhili, L. B. Dhiab. Management of Environmental Performance and Impact of the Carbon Dioxide Emissions (CO2) on the Economic Growth in the GCC Countries

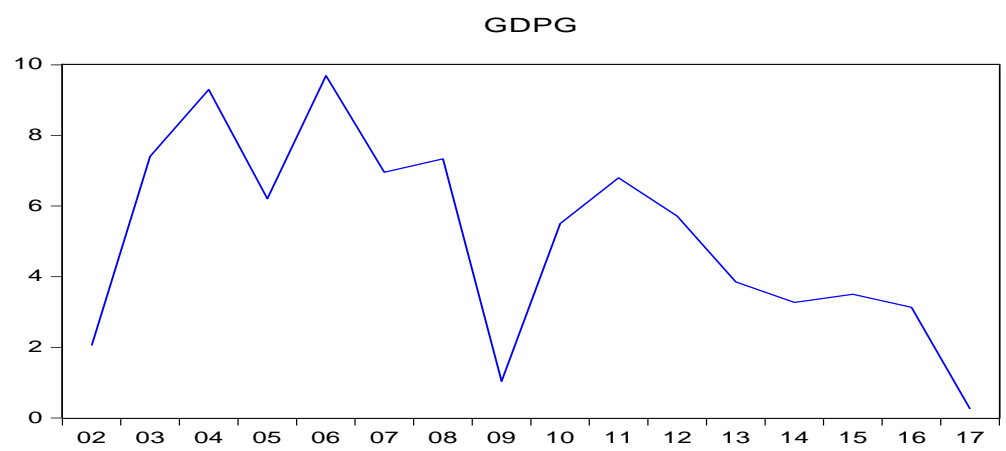

Figure 2. Average evolution of GDPG in GCC countries

To examine the relationship between environmental performance, $\mathrm{CO} 2$ emissions, and economic growth in the GCC countries, we used a standard model for the sample previously-cited. Especially, we estimated the GMM model system. Firstly, we present the descriptive statistics (table 3) for all the variables of our study such as environmental performance, economic growth, CO2 Emission, Trade, foreign direct investment and investment (Gross fixed capital formation). Secondly, we explore the results of the correlation matrix (table 3). Later, we display the unit root result and the order of integration is displayed in table 4. Thereafter, we talk about the Cointegration test with the results of Pedroni (2004) in table 5, and the Kao Residual Co-integration (1999) in table 6. Finally, we will finish with the Long-run estimates FMOLS and DOLS (table 7) and the Granger Causality Test (table 8).

Descriptive statistics. The statistics presented in table discloses the descriptive results of the different variables of the study. The average level of $\mathrm{CO} 2$ emission is $(59.879 \%)$, while the average level of EPI is $(60.253 \%)$ with a maximum of $(86.000)$ and a minimum of (44.040). The GDPG achieved an average of $(4.320 \%)$ with a negative minimum of $(-7.076 \%)$ and a positive maximum of $(17.320 \%)$. The average level of investment sets on the average of $(23.216 \%)$, which lightly near the median with a value-added equal to $(23.231 \%)$, and with a maximum value of $(34.523 \%)$, and a minimum value is $(14.627 \%)$ For the variables (FDI), and (TRADE), we achieve a similar remark to the point previously-cited: we are witnessing a positive mean equal respectively to $(3.011 \%)$ for (FDI), and (114.384\%) for (TRADE). These values are close to the median, respectively $(2.398 \%)$ and $(102.300 \%)$. For the square of the GDPG, the results show an average of $(53.9 \%)$ with a minimum of $(0.251 \%)$ and a maximum of $(68.488 \%)$

Finally, the Descriptive statistics results show positive coefficients for all the variables of the study.

Table 3. Descriptive statistics

\begin{tabular}{|c|c|c|c|c|c|c|c|}
\hline & GDPG & GDPSQ & EPI & CO2E & INVES & FDI & TRADE \\
\hline Mean & 4.320 & 53,986 & 60.253 & 59.879 & 23.216 & 3.011 & 114.384 \\
\hline Median & 4.399 & 19,969 & 60.130 & 63.285 & 23.231 & 2.398 & 102.300 \\
\hline Maximum & 17.320 & 68.488 & 86.000 & 74.050 & 34.523 & 15.751 & 191.878 \\
\hline Minimum & -7.076 & 0,251 & 44.040 & 9.214 & 14.627 & -3.152 & 61.862 \\
\hline Std. Dev. & 3.935 & 100,731 & 10.748 & 21.953 & 4.385 & 3.111 & 34.620 \\
\hline Skewness & -0.026 & 3,816 & 0.126 & 2.092 & 0.442 & 1.332 & 0.543 \\
\hline Kurtosis & 4.472 & 20,058 & 1.689 & 6.237 & 3.115 & 5.874 & 2.135 \\
\hline Jarque-Bera & 6.415 & 1396,892 & 5.273 & 82.766 & 2.348 & 45.409 & 5.709 \\
\hline Probability & 0.040 & 0,000 & 0.072 & 0.000 & 0.309 & 0.000 & 0.058 \\
\hline Sum & 306.694 & 5182,642 & 4277.990 & 2081.658 & 1648.331 & 213.807 & 8121.263 \\
\hline Sum Sq. Dev. & 1083.754 & 963933,100 & 8086.904 & 33736.890 & 1346.026 & 677.681 & 83897.830 \\
\hline Observations & 71 & 71 & 71 & 71 & 71 & 71 & 71 \\
\hline Sources: systing
\end{tabular}

Sources: systematised by the authors on the basis of $(2002,2017)$. 
H. Dkhili, L. B. Dhiab. Management of Environmental Performance and Impact of the Carbon Dioxide Emissions (CO2) on the Economic Growth in the GCC Countries

Correlation matrix. As for the pooled results in table 4, we release the following remarks: Firstly, we remark a negatives correlation between (GDPG) and the variables: (EPI) and (INVEST). These correlations are described with low coefficients equal to: $(-0,037)$ for the variable (EPI), $(-0.148)$ for $(C O 2 E)$ and $(-0,149)$ for (INVES). In the same case, we admired a positive correlation between GDPG and the variables: (FDI) and (TRADE), with also low coefficients equal to: $(0,135)$ for the FDI and $(0,003)$ for the variable (TRADE). Secondly, the results show a positives correlation between the variable (FDI) with all the variables of the study except the variable $(\mathrm{CO} 2 \mathrm{E})$. Also, we find positives correlation between the variable (TRADE) with all the variable of the study with strong coefficients.

Finally, the result shows that the level of correlation is low between the independent variables introduced in the econometric model. Therefore, we confirm the absence of multicollinearity.

Table 4. Correlation matrix

\begin{tabular}{|c|c|c|c|c|c|c|c|}
\hline & CO2E & GDPG & GDPSQ & EPI & INVES & FDI & TRADE \\
\hline CO2E & 1 & & & & & & \\
\hline GDPG & $-0,148$ & 1 & & & & & \\
\hline GDPSQ & $-0,217$ & 0,761 & 1 & & & & \\
\hline EPI & 0,506 & $-0,037$ & $-0,089$ & 1 & & & \\
\hline INVES & 0,236 & $-0,149$ & $-0,305$ & $-0,118$ & 1 & & \\
\hline FDI & 0,061 & 0,135 & $-0,034$ & $-0,001$ & 0,355 & 1 & \\
\hline TRADE & 0,473 & 0,003 & $-0,158$ & 0,184 & 0,201 & 0,322 & 1 \\
\hline
\end{tabular}

Sources: systematised by the authors on the basis of $(2002,2017)$.

Panel Unit Root Tests. The Panel Unit Root Tests is a method that is estimated by using Dickey and Fuller (1979) and Kwiatkowski et al. (1992). Especially, for the current study, we advance the Augmented Dickey-Fuller (F-ADF) unit root tests to check the stationary of each variable. After that, we used the augmented Dickey-Fuller (ADF) statistic. In this case, the null hypothesis support, the more negative, it is the stronger for the rejection of the hypothesis. And we demonstrate the existence of a unit roots at some level of confidence. In fact, the results of the Augmented Dickey-Fuller (ADF) and Phillips-Perron (PP) were tested for the six variables of the model displays in Table 5.

The results showed that in the level, the null hypothesis cannot be rejected for all the variables for both the two unit root test ADF and Phillips-Perron (2004); (PP) test. Finally, the variables (GDPG), (GDPGSQ), (EPI), (CO2E), (FDI), (TRADE), and (INVEST) are not stationary at the level of $5 \%$. And, the results rejected the null hypothesis of non-stationary. The unit roots tests confirm that each variable is integrated of order one.

Cointegration test and results. The cointegration test aims to check whether it exists a long run relationship association. Two statistics are used in the cointegration test of Johansen (1988); they are Trace test and Max-Eigen value. Table 3 presents the results of the trace and the maximum-eigenvalue tests from the Johansen (1980) and Johansen and Juselius (1990) Maximum Likelihood analysis. The results given in table 5 below suggest the existence of one cointegration vectors at $5 \%$ of significance for the Trace test and for the Max-eigenvalue. This result indicates that there is a long run association. In fact, the panel tests advance the cointegration results between the dimensions and groups when the dependent variable is economic growth. And empirically, the results prove the conditions of the rejection of the null hypothesis: which leads to noticing that economic growth is cointegrated for all the variables. These results are significant at the level of $5 \%$ for the two tests between the dimension (Pedroni's heterogeneous panel cointegration tests and Panel ADF-Statistic) this shows that the connections between the variables. We remark later some statistics results aren't significant for the results between group: such as for the panel and group versions of ADF-statistic and the group rho-statistic. 
H. Dkhili, L. B. Dhiab. Management of Environmental Performance and Impact of the Carbon Dioxide Emissions (CO2) on the Economic Growth in the GCC Countries

Table 5. Panel Unit Root Tests

\begin{tabular}{|c|c|c|c|c|c|c|c|c|c|}
\hline Tests & LLC & Prob & IPS & Prob & ADF-Fisher & Prob & PP-Fisher & Prob & $\begin{array}{c}\text { Order } \\
\text { of Integ }\end{array}$ \\
\hline GDPG & -3.274 & $(0.0005)$ & -2.425 & $(0.0076)$ & 26.163 & $(0.0102)$ & 28.85 & $(0.0041)$ & - \\
\hline$\Delta$ GDPG & -11.619 & $(0.000)$ & -9.482 & $(0.000)$ & 82.116 & $(0.000)$ & 113.87 & $(0.000)$ & $\mathrm{I}(1)$ \\
\hline GDPGSQ & -3.822 & $(0.000)$ & -2.646 & $(0.004)$ & 27.947 & $(0.005)$ & 36.121 & $(0.000)$ & - \\
\hline$\Delta$ GDPGSQ & -15.670 & $(0.000)$ & -11.622 & $(0.000)$ & 91.629 & $(0.000)$ & 140.251 & $(0.000)$ & $\mathrm{I}(1)$ \\
\hline EPI & 1.167 & $(0.8784)$ & 0.97 & $(0.8341$ & 10.612 & $(0.5624)$ & 40.792 & $(0.0001)$ & - \\
\hline$\Delta$ EPI & -3.725 & $(0.0001)$ & -8.793 & $(0.000)$ & 78.957 & $(0.000)$ & 109.816 & $(0.000)$ & $\mathrm{I}(1)$ \\
\hline CO2E & 1.531 & $(0.9371)$ & 2.287 & $(0.9889)$ & 20.242 & $(0.0626)$ & 5.735 & $(0.9288)$ & - \\
\hline$\Delta$ CO2E & -1.809 & $(0.0352)$ & -2.367 & $(0.009)$ & 33.116 & $(0.0009)$ & 21.313 & $(0.0414)$ & $\mathrm{I}(1)$ \\
\hline INVES & -2.192 & $(0.0142)$ & -1.626 & $(0.0519)$ & 17.425 & $(0.0649)$ & 13.688 & $(0.1877)$ & - \\
\hline$\Delta$ INVES & -5.277 & $(0.000)$ & -4.013 & $(0.0000)$ & 37.049 & $(0.000)$ & 38.336 & $(0.000)$ & $\mathrm{I}(1)$ \\
\hline FDI & -1.326 & $(0.0923)$ & -1.299 & $(0.0969)$ & 16.193 & $(0.1825)$ & 15.53 & $(0.2137)$ & - \\
\hline$\Delta$ FDI & -6.551 & $(0.000)$ & -5.358 & $0.000)$ & 47.971 & $(0.000)$ & 54.825 & $(0.000)$ & $\mathrm{I}(1)$ \\
\hline TRADE & -1.438 & $(0.0843)$ & -2.565 & $(0.0052)$ & 15.055 & $(0.1945)$ & 19.788 & $(0.0712)$ & - \\
\hline$\Delta$ TRADE & -7.246 & $0.000)$ & -5.035 & $(0.000)$ & 45.881 & $(0.000)$ & 37.135 & $(0.0002)$ & $\mathrm{I}(1)$ \\
\hline
\end{tabular}

Note: Probabilities for the Fisher-type tests are computed using an asymptotic Chi-square distribution. All other tests assume asymptotic normality. The choice of lag levels for IPS and Fisher-ADF test are determined by empirical realizations of the Schwarz Information Criterion. The LLC and Fisher-PP tests were computed using the Newey-West automatic bandwidth selection and Bartlett kernel. The panel Unit Root Test is conducted within an individual and intercept.

Sources: systematised by the authors on the basis of $(2002,2017)$.

Finally, through the previously-cited results, we finish by the conclusion which supports the existence of a panel long-run equilibrium relationship among the economic growth, EPI, CO2E, FDI, INVEST, and TRAD.

Table 6. Panel Co-integration test of Pedroni (2004)

\begin{tabular}{|c|c|c|c|c|c|c|c|}
\hline (Within-dimension) & Statistic & Prob. & Statistic & Prob. & (Between-group) & Statistic & Prob. \\
\hline Panel v-Statistic & -0.7257 & 0.7660 & -1.5584 & 0.9404 & Group rho-Statistic & 1.6818 & 0.9537 \\
\hline Panel rho-Statistic & 0.6561 & 0.7444 & 0.9492 & 0.8289 & Group PP-Statistic & -11.336 & $0.0000^{* \star \star}$ \\
\hline Panel PP-Statistic & -6.7469 & $0.0000^{* \star \star}$ & -3.4555 & $0.0003^{\star \star \star}$ & Group ADF-Statistic & -6.1581 & $0.0000^{* * *}$ \\
\hline Panel ADF-Statistic & -5.8647 & $0.0000^{\star \star \star}$ & -3.5542 & $0.0002^{* \star *}$ & & & \\
\hline
\end{tabular}

Note: The null hypothesis is that the variables are not cointegrated. Under the null hypothesis, all the statistics are distributed as standard normal distributions. The finite sample distribution for the seven statistics has been tabulated in Pedroni (2004). The P-values are in parentheses.

Sources: systematised by the authors on the basis of $(2002,2017)$.

Kao Residual Co-integration test. Table 7 presents the results of Kao's residual panel cointegration tests. The results of this table rejected the null hypothesis of no cointegration for the variables at the $1 \%$ significance level. Thereby, the results of Kao's residual panel cointegration tests reported in table 6 rejected the null hypothesis of no cointegration for the economic growth and the variables (EPI, CO2E, FDI, INVEST, and TRAD) at the 1\% significance level. This indicates the existence of cointegration.

Long-run estimates FMOLS method. The long-run relationship between economic growth, GDPDSQ, EPI, CO2E, FDI, INVEST, and TRAD using the panel cointegration technique due to (Pedroni 2004) reveals the following results: We use the results of panel Fully Modified OLS (FMOLS) exposed in table 7 above. More specifically, the results of the single-equation estimation techniques prove. 
H. Dkhili, L. B. Dhiab. Management of Environmental Performance and Impact of the Carbon Dioxide Emissions (CO2) on the Economic Growth in the GCC Countries

Table 7. Kao Residual Co-integration test

\begin{tabular}{|c|c|c|}
\hline & t-Statistic & Prob. \\
\hline ADF & -3.262 & $0.0006^{* *}$ \\
\hline Residual variance & 23.922 & \\
\hline HAC variance & 16.971 & \\
\hline
\end{tabular}

Sources: systematised by the authors on the basis of $(2002,2017)$.

Firstly, the average cointegration coefficient of environment performance (EPI) is equal to (1.094) and it is significant at $10 \%$. This remark is identical for the variables (INVEST), (FDI), and (TRADE), with a positive coefficient respectively equal to $(0.534),(2.333)$, and $(0.203)$ with the exception for the variable $\mathrm{CO} 2$ emission with a coefficient equal to $(-0.438)$ significant at the $10 \%$.

Thus, we prove that a (1\%) increase in economic growth leads on average to a $(1.094 \%)$ increase of the variable environment performance (EPI) also, we remark that a $1 \%$ increase in economic growth leads on average to a (53.4\%) increase of the variable investment (INVEST), and finally, we note that a (1\%) increase in economic growth leads on average to $(23.33 \%)$ for the variable FDI, and $(20.3 \%)$ for the variable trade openness (TRAD). For the variable $\mathrm{CO} 2$ emissions $(\mathrm{CO} 2 \mathrm{E})$, the results show that a $(1 \%)$ increase in economic growth leads on average to a $(43.8 \%$ ) decrease of the variable $\mathrm{CO} 2$ emissions (CO2E).

In addition, we remark that a $(-0.008 \%)$ variation of the GDPG square (GDPGSQ) is followed by positives variations of the variable (EPI) equal to (1.094\%), (INVEST) equal to $(0.534 \%)$, (FDI) equal to $(2.333 \%)$, (TRADE) equal to (0.203), and a negative variation of COE emissions equal to $(-0.438 \%)$.

As far as, we remark positive relations between economic growth and the variable environment performance (EPI) with significant coefficient equal to (1.094) at $10 \%$, and a coefficient equal to (2.333) for the variable (FDI), (0.534) the investment (INVEST), and equal to $(0.203)$ for the Variable (TRADE) the rest variables such as the variable $\mathrm{CO} 2$ emissions (CO2E) , and (GDPG), and the square of the (GDPG),the estimation of the DOLS results show a negative relation. These relationships are not significant at a level of $10 \%$.

Through these evoked, we notice that a positive variation of the economic growth leads to a strong and positive variation to the variable environment performance (EPI), investment (INVEST), and trade (TRAD). Also, a positive variation of the economic growth leads to a strong and negative variation to the variable $\mathrm{CO} 2$ emissions (CO2E). These last are significant at the level of $(1 \%)$ and $(10 \%)$.

Granger Causality Test. As an introduction to the results, it is postulated that the Granger causality analysis served to examine the cause and effect of the relationship between the variables of the study and during the study period. The results of Granger causality and regression coefficient for the economic growth and all variable of the study; (EPI), (CO2E), (FDI), (INVEST), and (TRAD), for all the sample composed by the GCC countries and during the period (2002-2018), are exposed in table 8.

Table 8. Long-run estimates FMOLS

\begin{tabular}{|c|c|c|c|c|}
\hline $\mathbf{0}$ & Coeff & Std.Error & t-Stat & Prob. \\
\hline GDPG & -0.359 & 0.447 & -0.802 & 0.426 \\
\hline GDPSQ & -0.008 & 0.042 & -0.179 & 0.859 \\
\hline EPI & 1.094 & 0.584 & 1.873 & $0.066^{*}$ \\
\hline CO2E & -0.438 & 0.448 & -0.977 & 0.333 \\
\hline INVES & 0.534 & 0.2 & 2.675 & $0.010^{* * *}$ \\
\hline FDI & 2.333 & 0.905 & 2.579 & $0.013^{* *}$ \\
\hline TRADE & 0.203 & 0.229 & 0.886 & 0.38 \\
\hline R-squared & 0.604 & S.E. of regression & 9.389 \\
\hline Adjusted R-squared & 0.533 & \multicolumn{2}{|c|}{ Long-run variance } & 61.044 \\
\hline \multirow{2**}{*}{ and * indicate the level of significance at 1\% and $10 \%$}
\end{tabular}

Sources: systematised by the authors on the basis of $(2002,2017)$. 
H. Dkhili, L. B. Dhiab. Management of Environmental Performance and Impact of the Carbon Dioxide Emissions (CO2) on the Economic Growth in the GCC Countries

Indeed, our results show a unidirectional relationship of the sample GCC countries between economic growth and the variables; (EPI), (INVEST), (FDI), and (TRADE) at the level of $5 \%$.

In addition, our panel Granger causality tests results reported in table 8, advanced that the variable CO2 Emissions (CO2E) do not Granger cause economic growth (GDPPC), with an insignificant level. Also, the results indicate that economic growth (GDPPC) have a positive impact on the variables; (EPI), (INVEST), (FDI), and (TRADE). And, we prove a negative unidirectional relation with the variable CO2 emissions (CO2E). This one isn't significant at the two levels $(1 \%)$ and $(5 \%)$.

Table 9. Granger Causality Test

\begin{tabular}{|c|c|c|c|}
\hline Null Hypothesis: & Obs & F-Statistic & Prob. \\
\hline GDPG does not Granger Cause CO2E & 84 & 0,0408 & 0.9600 \\
\hline CO2E does not Granger Cause GDPG & & 3,7481 & $0.0279^{* *}$ \\
\hline GDPSQ does not Granger Cause CO2E & 84 & 0,0678 & 0.9345 \\
\hline CO2E does not Granger Cause GDPSQ & & 2,3540 & $0.0862^{*}$ \\
\hline EPI does not Granger Cause CO2E & 90 & 6,3572 & $0.0027^{* *}$ \\
\hline CO2E does not Granger Cause EPI & & 1,2699 & 0.2861 \\
\hline INVES does not Granger Cause CO2E & 62 & 1,3215 & 0.2748 \\
\hline CO2E does not Granger Cause INVES & & 0,2073 & 0.8134 \\
\hline FDI does not Granger Cause CO2E & 84 & 2,8910 & $0.0614^{*}$ \\
\hline CO2E does not Granger Cause FDI & & 0,0352 & 0.9654 \\
\hline
\end{tabular}

${ }^{* *}$ and ${ }^{* * *}$ indicate the level of significance at $5 \%$ and $1 \%$

Sources: systematised by the authors on the basis of $(2002,2017)$.

Finally, we conclude that our results advance relationships between the variables described by:

- Unidirectional causality between CO2E and GDP growth and GDPSQ running from CO2E to growth.

- Unidirectional causality between EPI and CO2E running from EPI to CO2e.

- Unidirectional causality between FDI and CO2E running from FDI to CO2e

- Unidirectional causality between TRADE and CO2E running from TRADE to CO2e

- No causality between INVES and CO2E

Also, the result for the GCC countries doesn't support the carbon emissions EKC hypothesis.

Conclusions. The purpose of this paper is to understand the attitude of the economic growth towards the environmental components: the level of emission of $\mathrm{CO} 2$ emissions (ton metric) and the environmental performance. This relationship is studied based on the reaction of macroeconomic variables such as foreign direct investment, trade openness, and investment. The literature review reveals theoretical and empirical work in different contexts. For our study, we are interested in the context of the GCC countries.

In fact, the studies of Saidi and Mbarek (2017), Dkhili (2018), Boutabba, (2014), Shahbaz et al. (2013), Salahuddin et al. (2015), Shuai et al. (2017), Bekhet and Othman (2017), Liu et al. (2017), Kaushik et al. (2006), Ouyang and Lin (2017), Dkhili and Ben Dhiab (2019), He et al. (2017), and Zhang et al. (2017) result empirically from the existence of a unidirectional and positive relationship between environmental performance and growth economy. Some other researchers focused on the study of the linkage between the environmental performance and the variables macroeconomic as the foreign direct investment, the trade openness, the investment, and the $\mathrm{CO} 2$ emissions. In which, the results drawn by Altwaijri et al., (2004), Bohringer and Ochem, (2007), Sugiawan et al., (2019), Churchill et al., (2019), He et al., (2019a), Miao et al., (2019), Saini and Sighania (2019), Ershad and Haque (2019), Yang et al., (2019), and He et al., (2019b), indicate a positive interactions between the variables. 
H. Dkhili, L. B. Dhiab. Management of Environmental Performance and Impact of the Carbon Dioxide Emissions (CO2) on the Economic Growth in the GCC Countries

Actually, our research starts from the theoretical underpinning which supports the problematic of discovering the linkage between six key variables (GDPPC, EPI, TRAD, INVEST, FDI, and CO2E) and the meaning of these relationships. The methodological tools of the research methods try to measure the influence of economic growth on the other variables quoted above. We used the econometric approach embodied by the GMM method on a data panel composed of six GCC countries. The results prove positive unidirectional relations between economic growth and the variable economic growth and environmental performance (EPI), (FDI), (INVEST), (TRAD). Also, the results advanced a negative unidirectional relation with the variable economic growth and $\mathrm{CO} 2$ emissions (CO2E). These findings can also be associated with some implications for the GCC countries.

These results confirm those found by Ershad and Haque (2019), He et al., (2019b), Chen et al. (2019), Sheng et al. (2019), Azam et al., (2019), Bekun et al., (2019), Bakirtas and Atalay Cetin (2017) , Saidi and Mbarek (2017), and Miao et al., (2019).

The conclusion found for GCC countries proves a positive relationship between the variables of the study except for the variable $\mathrm{CO} 2$ emissions, the results showed a negative relationship. More concretely, the more economic growth improves in countries, the more they release carbon dioxide. This is seen clearly by encouraging foreign investment, open trade, investment. At the same time, these countries opt for maintaining a healthy environment, given the positive relationship between the growth economy and environmental performance. These findings can support development policy makers in the GCC countries to consider clean and environmentally friendly investment for sustainable urban development. The findings also help save the world from natural disasters and preserve the environment under sustainable development policies. It also provides a new perspective on the relationship between environmental performance, economic growth, and carbon dioxide emissions.

The results don't support the Environmental Kuznets Curve (EKC) in the GCC countries, and they can't be able to promote the validity of the $\mathrm{CO} 2$ emission against the EKC framework. Indeed, show that the GDPG and CO2 emission have a statistically insignificant negative impact on the carbon emission and its square has an insignificant negative effect on the carbon emissions both in the short-run and long-run.

Furthermore, the results of this study may be of great importance to policymakers and decision-makers for the development of energy policies in the GCC countries. Which contribute to reducing carbon emissions while maintaining Economic Growth.

Finally, this study opens up new insights for the GCC economy to maintain economic growth by controlling the environment from degradation through the efficient use of energy.

Author Contributions: For research articles with several authors, a short paragraph specifying their individual contributions must be provided. The following statements should be used conceptualization, D. H.; methodology, D. H.; software, D. H.; validation, D. H., and B. D. L.; formal analysis, D. H., and B. D. L.; investigation, D. H.; resources, D. H.; data curation, D. H.; writing-original draft preparation, D. H.; D. $H$ - review and editing, D. H., and B. D. L.; visualization, D. H., and B. D. L.; supervision, B. D. L project administration, B.D.L.; funding acquisition, B. D. L.

Funding: This research was funded by deanship of Scientific Research, Northern Border University and The APC was funded by grant $\mathrm{N} 0(435 / 000)$.

\section{References}

Acaravci, Ali, and Ilhan Ozturk. 2010. On the relationship between energy consumption, $\mathrm{CO} 2$ emissions and economic growth in Europe. Energy, 35(12), 5412-5420.

Ahmad, Najid, Liangsheng Du, Jiye Lu, Jianlin Wang, Hong-Zhou Li, and Muhammad Zaffar Hashmi. 2017. Modeling the $\mathrm{CO}_{2}$ emissions and economic growth in Croatia: Is there any environmental Kuznets curve? Energy 123: 164-72.

Das Neves Almeida, T. A., Cruz, L., Barata, E., \& Garcia-Sanchez, I. M. (2017). Economic growth and environmental impacts: An analysis based on a composite index of environmental damage. Ecological Indicators, 76, 119-130. 
H. Dkhili, L. B. Dhiab. Management of Environmental Performance and Impact of the Carbon Dioxide Emissions (CO2) on the Economic Growth in the GCC Countries

Garcia-Sanchez, Isabel-Maria, das Neves Almeida, Thiago Alexandre, \& de Barros Camara, Renata Paes. 2015. A proposal for a Composite Index of Environmental Performance (CIEP) for countries. Ecological Indicators, 48, 171-188.

Al-Mulali, Usama, Ilhan Ozturk, and Sakiru Adebola Solarin.2016. Investigating the environmental Kuznets curve hypothesis in seven regions: The role of renewable energy. Ecological Indicators, 67, 267-282.

Apergis, Nicholas, and llhan Ozturk.2015. Testing environmental Kuznets curve hypothesis in Asian countries. Ecological Indicators, 52, pp.16-22.

Apergis, Nicholas, and James E. Payne. 2009. CO2 emissions, energy usage, and output in Central America. Energy Policy, 37(8), 3282-3286.

Atasoy, Burak Sencer. 2017. Testing the environmental Kuznets curve hypothesis across the US: Evidence from panel mean group estimators. Renewable and Sustainable Energy Reviews, 77, 731-747.

Azam, Muhammad, and Abdul Qayyum Khan. 2016. Testing the Environmental Kuznets Curve hypothesis: A comparative empirical study for low, lower middle, upper middle and high income countries. Renewable and Sustainable Energy Reviews, 63 , 556-567.

Azam, Muhammad, Abdul Qayyum Khan, and Ilhan Ozturk. The effects of energy on investment, human health, environment and economic growth: empirical evidence from China. Environmental Science and Pollution Research (2019): 1-10.

Bakirtas, Ibrahim, and Mumin Atalay Cetin.2017. Revisiting the environmental Kuznets curve and pollution haven hypotheses: MIKTA sample. Environmental Science and Pollution Research, 24(22), 18273-18283.

Bekhet, Hussain Ali, and Nor Salwati Othman. Impact of urbanization growth on Malaysia $\mathrm{CO} 2$ emissions: Evidence from the dynamic relationship. Journal of cleaner production 154 (2017): 374-388.

Bekun, Festus Victor, Firat Emir, and Samuel Asumadu Sarkodie. Another look at the relationship between energy consumption, carbon dioxide emissions, and economic growth in South Africa. Science of The Total Environment 655 (2019): 759-765.

Bese, Emrah, and Salih Kalayci. 2019. Environmental Kuznets Curve (EKC): Empirical Relationship between Economic Growth, Energy Consumption, and CO2 Emissions: Evidence from 3 Developed Countries. Panoeconomicus, 1-26.

Bhattarai, Madhusudan, and Michael Hammig. 2001. Institutions and the environmental Kuznets curve for deforestation: a crosscountry analysis for Latin America, Africa and Asia. World development, 29(6), 995-1010.

Bilgili, Faik, Emrah Kocak, and Umit Bulut. 2016. The dynamic impact of renewable energy consumption on $\mathrm{CO} 2$ emissions: a revisited Environmental Kuznets Curve approach. Renewable and Sustainable Energy Reviews, 54, 838-845.

Bohringer, Christoph, and Patrick EP Jochem. «Measuring the immeasurable-A survey of sustainability indices». Ecological economics 63.1 (2007): 1-8.

Boutabba, Mohamed Amine. 2014. The impact of financial development, income, energy and trade on carbon emissions: Evidence from the Indian economy. Economic Modelling, 40(Supplement C), 33-41.

Cetin, Murat, and Eyup Ecevit. 2017. The impact of financial development on carbon emissions under the structural breaks: empirical evidence from Turkish economy. Journal of Economic \& Management Perspectives, 11(1), 64-78.

Chen, Yulong, Jincai Zhao, Zhizhu Lai, Zheng Wang, and Haibin Xia. Exploring the effects of economic growth, and renewable and non-renewable energy consumption on China's $\mathrm{CO} 2$ emissions: Evidence from a regional panel analysis. Renewable Energy (2019).

Chikalipah, Sydney. and Daniel Makina. 2019. Economic growth and human development: Evidence from Zambia. Sustainable Development.

Churchill, Sefa Awaworyi, Kris Ivanovski, and Mita Bhattacharya. «The role of ethnic diversity in sustainable environmental growth: new evidence across different income regions». Applied Economics 51.4 (2019): 398-408.

Cracolici, Maria Francesca, Cuffaro, Miranda, \& Nijkamp, Peter. 2010. The measurement of the economic, social and environmental performance of countries: A novel approach. Social indicators research, 95(2), 339

Dang, Phuong Thao. 2019. Sustainability comes from within: carbon dioxide emissions, FDI origin factor and institutional qualities in developing countries. Economia Politica (2019): 1-33.

Dickey, David. A., Wayne A Fuller. 1979. Distribution of the estimators for autoregressive time series with a unit root. Journal of the American statistical association, 74(366a), pp.427-431.

Echavarren, Jose M. 2017. From objective environmental problems to subjective environmental concern: A multilevel analysis using 30 indicators of environmental quality. Society \& natural resources, 30(2), pp.145-159.

Eren, Baris Memduh, Nigar Taspinar, and Korhan K. Gokmenoglu. 2019. The impact of financial development and economic growth on renewable energy consumption: Empirical analysis of India. Science of the Total Environment, 663, 189-197.

Ershad Hussain, M., Mahfuzul Haque. 2019. Is there any link between economic growth and the earth's environment? Evidence from 127 countries for the period 2007-2015. Journal of Environmental Economics and Policy, 8(2), pp.193-208.

Fodha, Mouez, and Oussama Zaghdoud. 2010. Economic growth and pollutant emissions in Tunisia: an empirical analysis of the environmental Kuznets curve. Energy Policy, 38(2), 1150-1156.

Gokmenoglu, Korhan K., Godwin Oluseye Olasehinde-Williams, and Nigar Taspinar. 2019. Testing the Environmental Kuznets Curve Hypothesis: The Role of Deforestation. In Energy and Environmental Strategies in the Era of Globalization , 61-83).

Grossman, Gene M., and Alan B. Krueger.1991. Environmental impacts of a North American free trade agreement (No. w3914). National Bureau of Economic Research. 
H. Dkhili, L. B. Dhiab. Management of Environmental Performance and Impact of the Carbon Dioxide Emissions (CO2) on the Economic Growth in the GCC Countries

Grossman, Gene M., and Alan B. Krueger. 1995. Economic growth and the environment. The quarterly journal of economics, 110(2), 353-377.

Grytten, Ola Honningdal, and Viktoriia Koilo. 2019. Evidence of the Environmental Kuznets Curve in Emerging Eastern European Economies. NHH Dept. of Economics Discussion Paper, (11).

He, Pinglin, Ying Zhang, Yuan Yuan, Ya Qiao, Lizhu Xin, and Xiaonan Zou. 2019. The Relationship between Environmental Taxation, Environmental Performance and Economic Growth: Comparative Study of Sweden and China 1985-2016. Ekoloji, 28(107), pp.401-410.

He, Zhengxia, Shichun Xu, Wenxing Shen, Ruyin Long, and Hong Chen. 2017. Impact of urbanization on energy-related CO2 emission at different development levels: Regional difference in China based on panel estimation. Journal of Cleaner Production, 140(Part 3), 1719-1730.

Jamali, Dima, Charlotte Karam, Juelin Yin, and Vivek Soundararajan. 2017. CSR logics in developing countries: Translation, adaptation, and stalled development. Journal of World Business, 52(3), pp.343-359.

Jayanthakumaran, Kankesu, and Ying Liu. 2012. Openness and the environmental Kuznets curve: evidence from China. Economic Modelling, 29(3), 566-576.

Johansen, Soren, \& Juselius, Katarina. 1990. Maximum Likelihood Estimation and Inference on Cointegration--With Applications to the Demand for Money. Oxford Bulletin of Economics and Statistics, 52(2), 169-210.

Kang, Yan-Qing, Tao Zhao, and Ya-Yun Yang.2016. Environmental Kuznets curve for CO2 emissions in China: A spatial panel data approach. Ecological Indicators, 63, 231-239.

Kao, Chihwa.1999. Spurious regression and residual-based tests for cointegration in panel data. Journal of Econometrics, $90(1)$ pp.1-44.

Kasman, Adnan, and Yavuz Selman Duman. 2015. CO2 emissions, economic growth, energy consumption, trade and urbanization in new EU member and candidate countries: a panel data analysis. Economic Modelling, 44, 97-103.

Khan, Syed Abdul Rehman. 2019. The nexus between carbon emissions, poverty, economic growth, and logistics operationsempirical evidence from Southeast Asian countries. Environmental Science and Pollution Research, 26, 13210-13220.

Lau, Lin-Sea, Chee-Keong Choong, and Yoke-Kee Eng. 2014. Investigation of the environmental Kuznets curve for carbon emissions in Malaysia: do foreign direct investment and trade matter?. Energy Policy, 68, 490-497.

Lee, Chien-Chiang, Yi-Bin Chiu, and Chia-Hung Sun.2010. The environmental Kuznets curve hypothesis for water pollution: Do regions matter?. Energy Policy, 38(1), 12-23.

Lesakova, Petra, and Ondřej Dobes. 2018. Economic Growth and CO2 Emissions in the Czech Republic. Vision 2020: Sustainable Economic Development and Application of Innovation Management from Regional expansion to Global Growth.

Liu, Yonghong, Gao, Chaochao, \& Lu, Yingying. 2017. The impact of urbanization on GHG emissions in China: The role of population density. Journal of Cleaner Production, 157, 299-309. doi: https://doi.org/10.1016/j.jclepro.2017.04, p.138.

Liu, Xuyi, Shun Zhang, and Junghan Bae.2017. The impact of renewable energy and agriculture on carbon dioxide emissions: Investigating the environmental Kuznets curve in four selected ASEAN countries. Journal of Cleaner Production, 164.1239-1247.

Mahmood, Nasir, Zhaohua Wang, Nazia Yasmin, Waqas Manzoor, and Atteeq ur Rahman. 2019. How to bend down the environmental Kuznets curve: the significance of biomass energy. Environmental Science and Pollution Research, 1-11.

Miao, Z., Balezentis, T., Tian, Z., Shao, S., Geng. Y., \& Wu, R. 2019. Environmental Performance and Regulation Effect of China's Atmospheric Pollutant Emissions: Evidence from «Three Regions and Ten Urban Agglomerations». Environmental and Resource Economics.

Ouyang, Xiaoling, \& Lin, Bogiang. 2017. Carbon dioxide (CO2) emissions during urbanization: A comparative study between China and Japan. Journal of Cleaner Production, 143, pp. 356-368. doi: https://doi.org/10.1016/j.jclepro.2016. pp.12.102

Ozturk, Ilhan, and Usama Al-Mulali.2015. Investigating the validity of the environmental Kuznets curve hypothesis in Cambodia. Ecological Indicators, 57, pp. 324-330.

Pablo-Romero, M. P., Cruz, L., \& Barata, E. (2017). Testing the transport energy-environmental Kuznets curve hypothesis in the EU27 countries. Energy Economics, 62, 257-269.

Pedroni, Peter. 2004. Panel cointegration: asymptotic and finite sample properties of pooled time series tests with an application to the PPP hypothesis. Econometric theory, 20(3), pp. 597-625.

Saboori, Behnaz, Jamalludin Sulaiman, and Saidatulakmal Mohd.2012. Economic growth and CO2 emissions in Malaysia: a cointegration analysis of the environmental Kuznets curve. Energy policy, 51, pp. 184-191.

Saboori, Behnaz, and Jamalludin Sulaiman. 2013. Environmental degradation, economic growth and energy consumption: Evidence of the environmental Kuznets curve in Malaysia. Energy Policy, 60, pp.892-905.

Saini, Neha, and Monica Sighania.2019. Environmental impact of economic growth, emission, and FDI: a systematic review of reviews. Qualitative Research in Financial Markets, 11, 81-134.

Salahuddin, Mohammad, Jeff Gow, and Ilhan Ozturk. 2015. Is the long-run relationship between economic growth, electricity consumption, carbon dioxide emissions and financial development in Gulf Cooperation Council Countries robust? Renewable and Sustainable Energy Reviews, 51, 317-326.

Shahbaz, Muhammad, Aviral Kumar Tiwari, and Muhammad Nasir. The effects of financial development, economic growth, coal consumption and trade openness on CO2 emissions in South Africa.2013a. Energy Policy 61 (2013): 1452-1459. 
H. Dkhili, L. B. Dhiab. Management of Environmental Performance and Impact of the Carbon Dioxide Emissions (CO2) on the Economic Growth in the GCC Countries

Shahbaz, Muhammad, Khan, Saleheen, \& Tahir, Mohammad lqbal. 2013b. The dynamic links between energy consumption, economic growth, financial development and trade in China: Fresh evidence from multivariate framework analysis. Energy Economics, 40, 8-21.

Sheng, Y., Miao, Y., Song, J., \& Shen, H. 2019. The Moderating Effect of Innovation on the Relationship between Urbanization and CO2 Emissions: Evidence from Three Major Urban Agglomerations in China. Sustainability, 11, 1633.

Shuai, C., Chen, X., Shen, L., Jiao, L., Wu, Y., \& Tan, Y .2017. The turning points of carbon Kuznets curve: evidences from panel and time-series data of 164 countries. Journal of cleaner production, 162, 1031-1047.

Sinha, Avik, Monika Gupta, Muhammad Shahbaz, and Tuhin Sengupta. 2019. Impact of corruption in public sector on environmental quality: Implications for sustainability in BRICS and next 11 countries. Journal of Cleaner Production.

Sugiawan, Yogi, Robi Kurniawan, and Shunsuke Managi. Are carbon dioxide emission reductions compatible with sustainable well-being? 2019. Applied Energy 242 (2019): 1-11.

Tamazian, Artur, and B. Bhaskara Rao. 2010. Do economic, financial and institutional developments matter for environmental degradation? Evidence from transitional economies. Energy Economics, 32(1), 137-145.

Tan, Francis, Hooi Hooi Lean, and Habibullah Khan.2014. Growth and environmental quality in Singapore: Is there any tradeoff? Ecological indicators, 47, 149-155.

Tang, Chor Foon, and Bee Wah Tan. 2015. The impact of energy consumption, income and foreign direct investment on carbon dioxide emissions in Vietnam. Energy, 79, 447-454

Tiwari, Aviral Kumar, Muhammad Shahbaz, and Qazi Muhammad Adnan Hye.2013. The environmental Kuznets curve and the role of coal consumption in India: cointegration and causality analysis in an open economy. Renewable and Sustainable Energy Reviews, 18, 519-527.

Yandle, Bruce, Maya Vijayaraghavan, and Madhusudan Bhattarai. 2002. The environmental Kuznets curve. A Primer, PERC Research Study, 02-01.

Yang, Fei, et al. Can reducing carbon emissions improve economic performance? .2019. Evidence from China. No.2019-13. Economics Discussion Papers, 2019.

Yin, Jianhua, Mingzheng Zheng, and Jian Chen.2015. The effects of environmental regulation and technical progress on CO2 Kuznets curve: An evidence from China. Energy Policy, 77, 97-108.

Zhang, Yue-Jun, Wei-Chen Yi, and Bo-Wen Li. The impact of urbanization on carbon emission: empirical evidence in Beijing Energy Procedia 75 (2015): 2963-2968.

Altwaijri et al., (2004) AlTuwaiji, S.A., Christensen, T.E. and Hughes li, K.E., 2004. The relations among environmental disclosure, environmental performance, and economic performance: a simultaneous equations approach. Accounting, organizations and society, 29(5-6), pp.447-471.

Ang, 2007) Ang, James B. 2007. CO2 emissions, energy consumption, and output in France. Energy policy 35(10), 4772-4778.

Chang (2015) Chang, Ming-Chung.2015. Room for improvement in low carbon economies of G7 and BRICS countries based on the analysis of energy efficiency and environmental Kuznets curves. Journal of Cleaner Production, 99, 140-151.

Dkhili, Hichem, Ben Dhiab, Lassad. 2018. The Relationship between Economic Freedom and FDI versus Economic Growth: Evidence from the GCC Countries. Journal of Risk and Financial Management, 11(4), 81.

Dkhili, Hichem. (2018). Environmental performance and institutions quality: evidence from developed and developing countries. Marketing and Management of Innovations, 3, 333-244.

Gill et al., (2018) Gill, Abid Rashid, Kuperan K. Viswanathan, and Sallahuddin Hassan.2018. A test of environmental Kuznets curve (EKC) for carbon emission and potential of renewable energy to reduce greenhouse gases (GHG) in Malaysia. Environment, Development and Sustainability, 20(3), 1103-1114.

$\mathrm{He}$ and Richard (2010) He, Jie, and Patrick Richard. Environmental Kuznets curve for $\mathrm{CO} 2$ in Canada. Ecological Economics, 69(5), 1083-1093.

Kaushik, H. B., Dasgupta, K., Sahoo, D. R., \& Kharel, G. 2006. Performance of structures during the Sikkim earthquake of 14 February 2006. Current Science, pp.449-455.

Kuznets, Simon. 1955. Economic growth and income inequality. The American economic review, 1-28.

Saidi, Kais, \& Mbarek, Mounir Ben. 2017. The impact of income, trade, urbanization, and financial development on CO2 emissions in 19 emerging economies. Environmental Science and Pollution Research, 24(14), 12748-12757. doi: 10.1007/s11356016-6303-3.

X. Дкхілі, Північний прикордонній університет (Саудівська Аравія), Університет Джендуба (Туніс);

Л. Б. Дхіаб, Північний прикордонній університет (Саудівська Аравія).

Ефективне управління природоохоронною діяльністю: вплив викидів двоокису вуглецю (СО2) на економічне зростання арабських держав Перської затоки

У даній роботі узагальнені аргументи та контраргументи в рамках наукової дискусії з питань ефективності управління природоохоронною діяльністю, зокрема щодо зменшення викидів двоокису вуелецю та її впливу на економічне зростання країн. Основною метою проведеного дослідження $є$ емпірична перевірка гіпотези екологічної кривої Кузнеия для арабських країн Перської затоки. Систематизація літературних джерел та підходів до розв'язання проблеми 
H. Dkhili, L. B. Dhiab. Management of Environmental Performance and Impact of the Carbon Dioxide Emissions (CO2) on the Economic Growth in the GCC Countries

моделювання еколого-економічної взаємодії засвідчила, що актуальними залишаються питання дослідження зв'язку між економічним розвитком та рівнем забрудненням навколишнього середовища. Дослідження гіпотези екологічної кривої Кузнеия для арабських країн Перської затоки в статті здійснено в наступній логічній послідовності: побудова системи моделей GMM; коінтеграційний тест Педроні; залишковий коінтеграційний тест Као) та причинні тести Грейнджера.

Об'єктом дослідження обрано арабські країни Перської затоки, періодом дослідження обрано 2002-2018 роки.

Представлені результати емпіричного аналізу засвідчили односпрямовані причинно-наслідкові зв'язки між економічним зростанням та всіма ендогенними змінними (індекс екологічної ефрективності, рівень відкритості торгівлі, прямі іноземні інвестиції) запропонованої економіко-математичної моделі. Ці відносини є статистично значущими на рівні 5\%. Дослідження емпірично підтверджує та теоретично доводить несуттєвий та однонаправлений зв'язок між економічним зростанням та викидами двоокису вуглецю. Автори спростовують гіпотезу екологічної кривої Кузнеия для арабських країн Перської затоки. Результати проведеного дослідження можуть бути корисними при побудові політики арабських країн Перської затоки щодо зменшення середнього рівня викидів двоокису вуглеию та побудови ефективної системи управління природоохоронною діяльністю.

Ключові слова: екологічні показники, екологічна крива Кузнеця, викиди двоокису вуглецю.

Manuscript received: 30.08.2019.

(C) The author(s) 2019. This article is published with open access at Sumy State University. 